\title{
The Concept of Audio-Visual Evidence In The Criminal Violation According To Criminal Procedural Law
}

\author{
Kusnanto \\ \{kusnantojayabaya@gmail.com\} \\ Doctor of Law, Universitas Jayabaya, Jakarta, Indonesia
}

\begin{abstract}
Electronic evidence in the form of information and / or electronic documents is valid evidence in the Criminal Procedure Code that can substitute letters and serves as independent evidence and an extension of evidence. These three statuses are not mentioned the Criminal Procedure Code (KUHAP), but the regulations are explained in some special laws and legal instruments issued by the Supreme Court (MA). Electronic evidence is valid in criminal justice practice and is regulated in some special laws and legal instruments issued by the Supreme Court (MA). This normative legal research provides accurate description of the current existing facts in the form of secondary data on primary legal material or secondary materials for tertiary legal materials. It was found that the concept of audio-visual recordings as evidence is valid if the audio-visual recordings substantively describe the occurrence of a criminal event. The recognition of audio-visual recordings as evidence is based on the rights and obligations of the perpetrators and victims of criminal acts. Every perpetrator has the responsibility regarding general criminal acts that have been committed without being limited by inhibited by the general criminal procedure law. Every victim of a crime has the right to receive compensation and rehabilitation for the suffering and loss that they have experienced without being intervened by the general criminal procedure law. This new concept regards audio visual recording that describes the occurrence of a criminal act must be taken as evidence being verified for its authenticity. The verification can be carried out using a variety of methods aimed at assessing the truth and authenticity of the legal facts shown in the audio-visual recording.
\end{abstract}

Keywords: Means of Proof, Audio-Visual, Criminal Procedure

\section{Introduction}

The flow of a criminal investigation begins with filing an indictment by the Public Prosecutor (Jaksa Penuntut Umum - JPU) to the verdict by the judge in court. One of the stages in the examination of a criminal act is presenting evidence. It is a means of determining the guilt or innocence of the defendant. M. Yahya Harahap stated that juridically, evidence is a provision that determines outlines and guidelines on the various ways justified by law to prove the guilt charged against the accused. Such particular phase entails a provision that ascertains proper evidence justified by law to be used by a judge to prove a defendant's guilt. The court, in this case, should not arbitrarily act when proofing the defendant's guilt [1].

According to Hamzah, proving the defendant's culpability is the most crucial part of the criminal procedure [2] since it plays an essential role in determining the judge's conviction to declare someone guilty [3]. It is also an important stage in examining criminal cases in court 
both in terms of the Criminal Justice System and Criminal Procedure Law (Formeel Strafrecht and straf Procesrecht, respectively). Evidence assessment is a crucial step in the criminal case, for it is a determining stage to sentence the defendant.

Criminal Procedure Law aims to achieve material truth [4]. A criminal act that occurred must be examined from its roots based on valid evidence tools submitted in court proceedings. The achievement of material truth will bring the value of substantial justice in the enforcement of criminal law in concreto. Proof of criminal acts appears in Chapter XVI Part Four Article 183-Article 189 of Law Number 8 of 1981 concerning Criminal Procedure Law, commonly referred to as criminal procedural law in the Criminal Law Procedure Code (Kitab Undangundang Hukum Acara Pidana-KUHAP). It governs general legal matters (lex generalis) and serves as a guideline for criminal law enforcers. The Special Criminal Law Procedure Code is regulated outside the KUHAP and is commonly called special law (lex specialis). The Special Criminal Procedure Code also regulates matters on proof of a criminal act.

Based on the provisions in Article 183 of the KUHAP, a judge may not impose a sentence on a person unless two valid pieces of evidence are presented and convinced of a defendant's culpability in a criminal act. The provisions also aim to guarantee the perpetuation of truth, justice, legal certainty, and human rights for an individual and every Indonesian citizen accused of committing a crime. The current rapid development of information technology has changed various fields of life, including in the field of Criminal Procedure Law. The inexplicit form of the electronic device has not yet been regulated within the KUHAP. It ranges from electronic information, electronic data or documents, examination of witnesses using audio-visual (teleconference), microfilm, radio cassette recordings, Video Compact Disk (VCD), Digital Versatile Disk (DVD), photographs, facsimiles, recordings from the Closed-Circuit Television (CCTV), Short Message Service (SMS) and Multimedia Messaging Service (MMS).

The appraisal of the Supreme Court (Mahkamah Agung-MA) in their letter to the Minister of Law and Human Rights Number 39 / TU / 88/102 / Pid differs from the decision of the Constitutional Court (MK) Number 20 / PUU-XIV / 2016. The latter states that Electronic Information and/or Electronic Documents cannot be used as evidence if it is not authorized within the context of law enforcement at the behest of the Police, Attorney General Office, and/or other specific law enforcement institutions. Based on the Constitutional Court's decision, CCTV is ineligible as legal evidence in court if its installation and recording are not at the behest of the law enforcers mentioned above, although almost every house in big cities, public facilities, and other public places have video surveillance to monitor the safety of certain vicinities. In other words, CCTV is no longer useful as it was originally intended, namely for evidence in court and security measures.

Based on some of these laws and regulations, electronic evidence, in some special criminal laws, is formulated explicitly and has the power as legal evidence [5]. However, there are differences in policies regarding the status of electronic evidence. On the one hand, it is recognized as an extension of evidence, while on the other hand, it is considered as independent evidence [6].

This study sees the concept of proof as provisions that regulate evidence justified by law and means of the judge to prove the defendant's guilt. In this regard, the judge must always be careful, attentive, and mature in assessing and considering the evidence. The judge must examine the extent to which the minimum limit of power of proof (bewijs krachts) of each piece of evidence should be stipulated in Article 184 of the KUHAP. 


\section{Research Methods}

This study used normative legal research by providing an accurate picture of the existing facts, both in secondary data on primary legal materials and secondary materials for tertiary legal materials. The approach used in normative legal research allows researchers to take advantage of the findings of empirical legal science and other sciences to benefit, analyze, and explain law without changing the character of legal science as a normative science [7].

\section{Results and Discussion}

Essentially, criminal law requires order and legal certainty in society. The order and certainty referred to in criminal law have the objective of ensuring that every community member can perform their obligations and obtain the rights they are entitled to.

The problem regarding audio-visual recordings that are not recognized in a general criminal act unless the law enforcement authorizes it is its conflict with the fulfilment of rights and obligations of criminal offenders and the victims. Audio-visual recordings in today's technology era are substantial evidence in supporting the investigation process of criminal cases $[8]$.

The limitation on the admissibility of audio-visual recordings as evidence in procedural law gives uncertainty for perpetrators of their imminent sentence. Concrete audio-visual recordings that certainly will provide a descriptive account of the case are insufficient as a legal basis for law enforcement to impose criminal sanctions. This scenario aggravates uncertainty and hampers objectivity when it comes to assessing the evidence. The criminal procedural law that formally regulates examination, trial, and evidence excludes audio-visual recordings as evidence. That is, it indirectly permits perpetrators and victims of general crimes to become unreliable with their information and testimony.

Audio-visual recordings that can provide a concrete and descriptive account of a general criminal act should be used as evidence and consideration for the law enforcement officials in assessing the truth and avoiding distortion of the testimony of the victims of general crimes. Victims of a general crime should testify clearly and truthfully, and law enforcement officials must also examine their testimony.

The refusal to acknowledge audio-visual recordings as evidence in a general crime has contributed to a deteriorating sense of security and protection because the public feels more protected by the presence of audio-visual security devices. Yet, the audio-visual recordings containing an incident of a general criminal act are inadmissible according to the criminal procedural law. The audio-visual recording admitted as evidence is recording installed by law enforcement. This raises the question that, "Is the audio-visual device installed at the behest of the law enforcement officials as a means of security and admissible at the court as evidence sufficient to cover the spread of the people?

The problematic discourse of audio-visual recordings as evidence can be considered a dichotomy between an authorized installation of audio-visual recordings and its unauthorized counterpart that caused the latter's rejection at the court. The facts illustrate the gap between material criminal law and formal criminal law in responding to legal problems. Such a gap must not exist in the first place. This is based on the fact that the principle nulum delictum, noela poena sine previa lege poenali as a fundamental principle in criminal law cannot be applied only due to the absence of harmony between material criminal law and formal criminal law. The 
formal criminal law, which is asynchronous with the material criminal law, makes general criminal acts listed in the material criminal law inapplicable. This results in a juridically applicable criminal law inadequate to provide legal certainty for the community (especially for perpetrators and victims), even though substantively, the incidents of general crimes that have occurred are documented.

Nulum delictum, noela poena sine previa lege poenali as a fundamental principle in criminal law [9], has a universally philosophical objective to deliver legal certainty for perpetrators and victims and fair distribution of rights and responsibility relevant to an incident. The general criminal procedural law that considered audio-visual recordings as invalid evidence at court unless those installed by law enforcers has resulted in the inconsistency of the principle in its praxis. A sophisticated and futuristic concept is needed, namely an evidential concept that can make a restorative contribution to the inconsistency between the substance of the criminal law and the applicable criminal procedural law.

According to the substance of criminal law and criminal procedural law, the gap resulting from different conceptions of evidence must be abolished so that audio-visual recordings in all forms and categories can ensue the philosophical aspiration of the law, namely: legal justice, legal certainty, and legal benefits. The concept offered above is expected to contribute to the community's legal needs and thus granted admissibility for the privately installed audio-visual recording devices in a trial.

The reduction or addition of audio-visual recording evidence will have a major impact on the process of examination, evidence assessment, and decisions for the perpetrators of general crimes. Therefore, a significant factor in the process of evidence assessment in a general crime should be the substance of truth and authenticity of a crime captured by an audio-visual recording and not on the official status of the device from which the audio-visual recording was produced.

\section{Conclusion}

The concept of proving audio-visual recordings in theory as evidence under the criminal procedural law is recognized as long as the material substantively describes a criminal event's occurrence. The concept of admissibility of audio-visual recordings as evidence is based on the rights and obligations of the perpetrators and victims of criminal acts. Every perpetrator must assume responsibility for a crime that has been committed without being impeded by what is and is not applicable within the framework of general criminal procedural law. This deliverance from formal hindrance in the general criminal procedural law must also be applicable to every victim of a crime to access their rights of receiving compensation and rehabilitation for the suffering and loss inflicted by a crime. The new concept that has been offered requires that every audio-visual recording that captured a criminal act be considered descriptively and demanded recognition as evidence with a certain authentication process to assess its accuracy and authenticity. Authentication can be conducted using various methods to determine the truth and authenticity of legal facts in the audio-visual recording. 


\section{References}

[1] Antoni, Veri, 'THE POSITION OF INDIRECT EVIDENCE AS VERIFICATION TOOLS IN THE CARTEL CASE', Mimbar Hukum - Fakultas Hukum Universitas Gadjah Mada, 26.1 (2014) $<$ https://doi.org/10.22146/jmh.16059>

[2] Mursyid, Ali Masyhar, 'CRITICIZE THE USE OF ANALOGY PROHIBITION IN CRIMINAL LAW', Mimbar Hukum - Fakultas Hukum Universitas Gadjah Mada, 27.1 (2015) <https://doi.org/10.22146/jmh.15903>

[3] Simonato, Michele, 'Defence Rights and the Use of Information Technology in Criminal Procedure', Revue Internationale de Droit Penal, 2014 <https://doi.org/10.3917/ridp.851.0261>

[4] Tosza, Stanislaw, 'All Evidence Is Equal, but Electronic Evidence Is More Equal than Any Other: The Relationship between the European Investigation Order and the European Production Order', New Journal of European Criminal Law, 11.2 (2020) <https://doi.org/10.1177/2032284420919802>

[5] M.Yahya Harahap, Pembahasan Permasalahan dan Penerapan KUHAP (Pemeriksaan Sidang Pengadilan, Banding, Kasasi dan Peninjauan Kembali, (Jakarta : Sinar Grafika, 2012), p.273.

[6] Hamzah, Andi Hukum Acara Pidana Indonesia, Jakarta : Sinar Grafika (2014).

[7] Mulyadi, Lilik Hukum Acara Pidana (Normatif, Teoretis, Praktik dan Permasalahannya), Bandung : Alumni (2012).

[8] Suseno, Sigid Yurisdiksi Tindak Pidaan Siber, Bandung: Refika Aditama (2012).

[9] Ibrahim, Johni. Teori dan Metodologi Penelitian Hukum Normatif,Cetakan III, Malang : Bayumedia Publishing (2007). 